\title{
Title:
}

\section{Esophageal pharmacobezoar: a very unusual complication of enteral nutrition use}

\section{Authors:}

José López González, Isabel Moreno Moraleda, Pedro Pablo Amado Villanueva, Noelia Campos Serrano

DOI: $10.17235 /$ reed.2022.8655/2022

Link: PubMed (Epub ahead of print)

Please cite this article as:

López González José, Moreno Moraleda Isabel, Amado Villanueva Pedro Pablo, Campos Serrano Noelia. Esophageal pharmacobezoar: a very unusual complication of enteral nutrition use. Rev Esp Enferm Dig 2022. doi:

$10.17235 /$ reed.2022.8655/2022.

This is a PDF file of an unedited manuscript that has been accepted for publication. As a service to our customers we are providing this early version of the manuscript. The manuscript will undergo copyediting, typesetting, and review of the resulting proof before it is published in its final form. Please note that during the production process errors may be discovered which could affect the content, and all legal disclaimers that apply to the journal pertain. 


\section{Esophageal pharmacobezoar: a very unusual complication of enteral nutrition use}

José López González, Isabel Moreno Moraleda, Pedro Pablo Amado Villanueva, Noelia Campos Serrano

UGC Aparato Digestivo. Hospital Universitario Torrecárdenas (Almería)

Corresponding autor: José López González. Email: pepe_1993_17@hotmail.com

Keywords: Pharmacobezoar. Enteral nutrition. Esophageal obstruction.

Mr. Editor:

Enteral nutrition in intensive care has been a great advance in medicine, due to its benefit, cost-effectiveness and few complications. Bronchoaspiration, diarrhea, regurgitation or mechanical problems are the main adverse effects. Esophageal obstruction by bezoar is a very infrequent complication, and there are only a few cases described in the literature.

\section{CLINICAL CASE}

Male, 73 years-old, admitted to ICU due to cardiorespiratory arrest after an ischemic stroke, who had a nasogastric tube for enteral nutrition (Glucerna ${ }^{\circ}$ ), which he maintained for 28 days, with initially good tolerance. On the 28th day of stay in ICU, the tube needed to be replaced due to its removal during postural changes, without being able to reposition it despite several attemps. We observe an obstruction to the passage of the new tube when we attempt to insert in, so an upper enndoscopy was performed. We observed an impaction of the enteral nutrition food mold at $28 \mathrm{~cm}$ of the dental arch, occupying the entire esophageal lumen (figure 1A). Fragmentation was performed with a polypectomy loop, but disimpaction was very laborious, requiring the administration of Coca-cola ${ }^{\circledR}$ injected over the hardest mold. Finally, we were able to extract the largest fragments with a Roth backet and continue to the gastric chamber (figure 1B).

DISCUSSION 
Bezoars are collections of undigested material accumulated in the digestive tract. In the case of pharmacobezoars, their origin is drug-related. Gastroesophageal reflux, prolonged decubitus, the use of sedatives and anticholinergics, formulas rich in casein, alterations in bowel motility and malposition of the tube favor their formation ${ }^{1}$. For its resolution, the use of endoscopic methods (polypectomy loops, biopsy forceps or baskets) and chemical methods, such as $\mathrm{Coca}-\mathrm{Cola}^{\circledR}$ or sodium bicarbonate, have been described in the literature, as in the article by Lin et $\mathrm{al}^{2}$ published in this journal, and both can be combined. $\mathrm{N}$ acetylcysteine, gastrografin or pancreatic enzymes can also be used ${ }^{3}$.

Therefore, it is a complication to consider in patients admitted to the ICU with nutritional support through a feeding tube. Routine washing of the tube, elevation of the headrest, the use of small caliber tubes and the use of prokinetics are recommended for prevention. In those cases with a tendency to reflux, delayed gastric emptying or prolonged need for enteral nutrition, the use of a nasojejunal tube or gastrostomy can be considered ${ }^{4}$.

\section{BIBLIOGRAPHY}

1) Amir Q, Bhakta P, Raman R et al. Esophageal bezoar formation due to solidification of enteral feed administered through a malpositioned nasogastric tube: case report and review of the literature. Acta Anaesthesiologica Taiwanica. 2012(50):188-190.

2) Lin L, Wang C, Wu J et al. Gastric phytobezoars: the therapeutic experience of 63 patients in Nothern China. Revista Española Enfermedades Digestivas. 2020; 112 (1):12-15

3) Gil F, Carmona FJ. Oesophageal bezoar as a complication of enteral nutrition in critically ill patients. Two case studies. Intensive and Critical Care Nursing. 2016 (32): $29-32$.

4) Iturralde J, Osés I, Roldán J et al. Obstrucción esofágica por bezoar relacionada con nutrición enteral. Medicina Intensiva. 2000 (24):81-84 


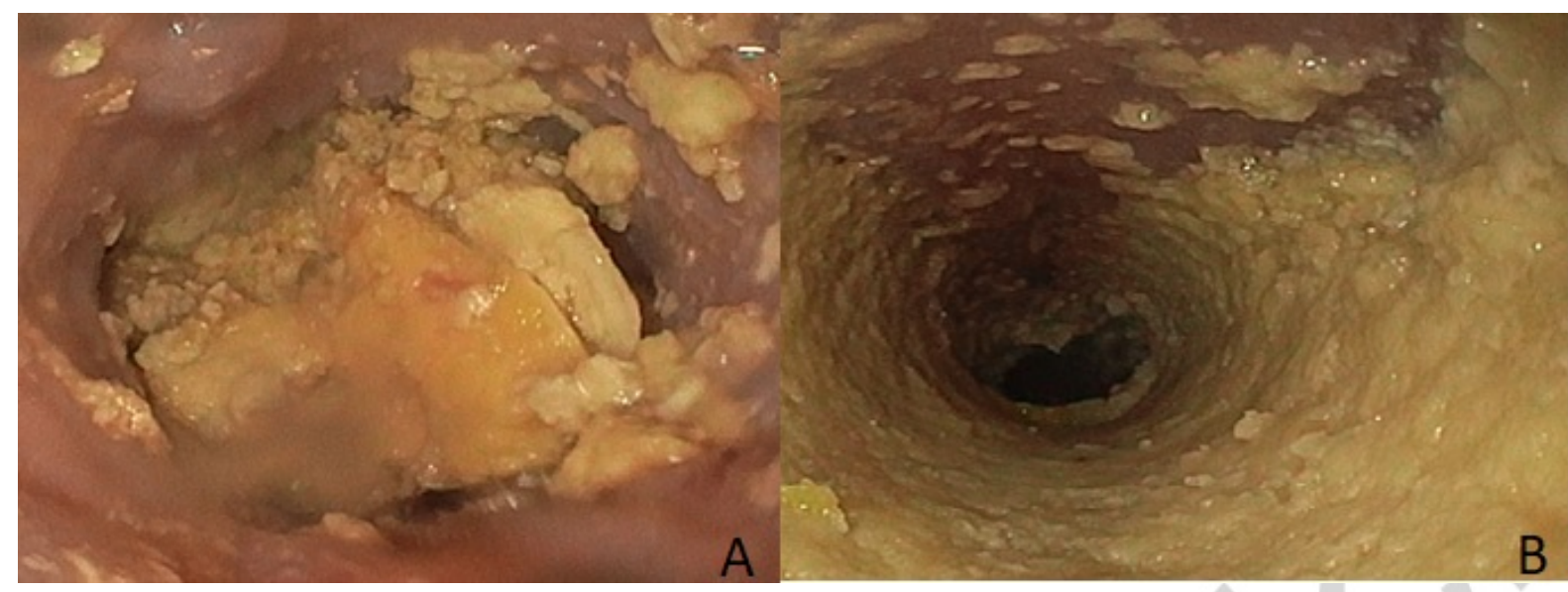

FIGURE 1. A: Mold of enteral nutrition impacted in the middle esophagus. B: Esophageal mucosa upholstered by enteral nutrition remnants after removal of the impacted mold. 